\title{
Respon Tanaman Jagung (Zea mays L.) Terhadap Pemberian Biochar Sabut Kelapa dan Pupuk Kandang Sapi
}

\author{
${ }^{1}$ Ledi Aprillia Pelawi, ${ }^{2}$ Mapegau, ${ }^{2}$ Yulia Alia \\ ${ }^{1}$ Alumni Fakultas Pertanian Universitas Jambi \\ ${ }^{2}$ Jurusan Agroekoteknologi Fakultas Pertanian, Universitas Jambi \\ Jl. Raya Jambi - Ma. Bulian KM. 15 Kampus Pinang Masak, Mendalo Darat Jambi 36361 \\ 1'e-mail korensponden : ledi.aprilia97@yahoo.com
}

\begin{abstract}
This study aims to determine the response of Bisma cultivar corn plants to the combination of coconut husk biochar and cow manure. The research was conducted at the Teaching and Research Farm of the Faculty of Agriculture, Jambi University which lasted for 4 months, from May to August 2019. The research location was at an altitude of $35 \mathrm{~m}$ above sea level. This study used a two-factor factorial randomized block design (RBD). The first factor is coconut coir biochar (b) with 3 levels, without giving coconut coir biochar (b0) (0 tonnes ha $\left.a^{-1}\right)$, b1 (5 tonnes ha $\left.a^{-1}\right)$, and b2 (10 tonnes ha $\left.{ }^{-1}\right)$. The second factor is cow manure $(p)$ with 3 levels, without of cow manure $(p 1)\left(0\right.$ ton ha $\left.a^{-1}\right), p 2\left(15\right.$ tonnes ha $\left.a^{-1}\right)$ and $p 3\left(30\right.$ tonnes ha $\left.a^{-1}\right)$, so there are 9 treatment combinations, namely b0p0, b0p1, b0p2, b1p0, b1p1, b1p2, b2p0, b2p1, and b2p2. The variables observed were plant height, total leaf area, seed weight per ear, and maize yield. To see the effect of the treatment on the observed variables, the data were analyzed statistically using variance and further tests using LSD at the level of $p=0.05$. The results showed that the interaction between coconut husk biochar and cow manure and coconut husk biochar factors did not significantly affect all observed variables. The application of cow manure had a significant effect on plant height growth, total leaf area, seed weight per ear and maize yield. Application of cow manure at a dose of 15 tons ha ${ }^{-1}$ gave the best growth and yields on maize
\end{abstract}

Keywords: biochar, corn, cow manure.

\begin{abstract}
Abstrak. Penelitian ini bertujuan untuk mengetahui respon tanaman jagung kultivar Bisma terhadap kombinasi pemberian biochar sabut kelapa dengan pupuk kandang sapi. Penelitian dilaksanakan di Teaching and Research Farm Fakultas Pertanian Universitas Jambi yang berlangsung selama 4 bulan, dari bulan Mei hingga Agustus 2019. Lokasi penelitian berada pada ketinggian 35 m dpl. Penelitian ini menggunakan Rancangan Acak Kelompok (RAK) pola faktorial dua faktor. Faktor pertama biochar sabut kelapa (b) dengan 3 taraf, tanpa pemberian biochar sabut kelapa (b0) (0 ton ha $\left.{ }^{-1}\right)$, b1 (5 ton ha $\left.{ }^{-1}\right)$, dan b2 (10 ton $\left.\mathrm{ha}^{-1}\right)$. Faktor kedua, pupuk kandang sapi (p) dengan 3 taraf, tanpa pemberian pupuk kandang sapi (p0) $\left(0\right.$ ton ha $\left.\mathrm{h}^{-1}\right)$, p1 (15 ton ha${ }^{1}$ ), dan p2 (30 ton $\left.\mathrm{ha}^{-1}\right)$, sehingga tedapat 9 kombinasi perlakuan, yakni b0p0, b0p1, b0p2, b1p0, b1p1, b1p2, b2p0, b2p1, dan b2p2. Variabel yang diamati yaitu tinggi tanaman, luas daun total, bobot biji per tongkol, dan hasil tanaman jagung. Untuk melihat pengaruh perlakuan terhadap variabel yang diamati, maka data dianalisis secara statistik dengan menggunakan sidik ragam dan uji lanjut menggunakan $B N T$ pada taraf $\mathrm{p}=0,05$. Hasil penelitian menunjukkan bahwa interaksi antara biochar sabut kelapa dengan pupuk kandang sapi serta faktor biochar sabut kelapa tidak berpengaruh nyata terhadap semua variabel yang diamati. Pemberian pupuk kandang sapi berpengaruh nyata terhadap pertumbuhan tinggi tanaman, luas daun total, bobot biji per tongkol dan hasil tanaman jagung. Pemberian pupuk kandang sapi dengan dosis 15 ton ha ${ }^{-1}$ memberikan pertumbuhan dan hasil terbaik pada tanaman jagung
\end{abstract}

Kata kunci : biochar, jagung, pupuk kandang.

\section{PENDAHULUAN}

Komoditas jagung mempunyai fungsi multiguna (4F), yaitu untuk pangan (food), pakan (feed), bahan bakar (fuel), dan bahan baku industri (fiber). Dalam ransum pakan ternak, terutama unggas, jagung merupakan komponen utama dengan proporsi sekitar $60 \%$. Diperkirakan lebih dari 58\% kebutuhan jagung dalam negeri digunakan untuk pakan, sedangkan untuk pangan hanya sekitar 30\%, dan sisanya untuk kebutuhan industri lainnya dan benih (Kementan, 2013). Potensi produktivitas jagung varietas komposit mencapai 6-8 ton ha ${ }^{-1}$ pipilan kering (Balitbangtan Pertanian, 2012), Kementan menyatakan, permasalahan sisi produksi jagung nasional antara lain, produktivitas rata-rata nasional yang belum bisa menembus 6 ton ha $^{-1}$, kurang efisiennya biaya produksi, inkontinuitas produksi, dan lokasi produksi yang tidak dekat lokasi pasar, khususnya lokasi industri pakan ( Kementan, 2016). Salah satu penyebab rendahnya produktivitas jagung tersebut adalah karena sebagian besar diusahakan pada tanah Ultisol dengan sifat fisik dan biologi yang kurang baik seperti reaksi masam, kadar Al tinggi sehingga menjadi racun bagi tanaman dan menyebabkan fiksasi $\mathrm{P}$, serta rendahnya ketersediaan unsur hara makro $(\mathrm{N}, \mathrm{P}, \mathrm{K})$ dalam tanah. Reaksi tanah yang sangat masam menyebabkan tanah kehilangan kapasitas tukar kation dan kemampuan menyimpan hara. Oleh karena itu perlu dilakukan upaya untuk mengatasi kendala tersebut.

Salah satu upaya yang dapat dilakukan adalah penerapan teknologi budidaya berupa pemberian bahan organik antara lain pupuk kandang sapi. Selain mengandung unsur hara makro seperti N, P dan K serta unsur mikro seperti $\mathrm{Mn}$, Fe, dan $\mathrm{Zn}$, pupuk kandang sapi juga dapat meningkatkan porositas tanah dan secara biologis meningkatkan aktifitas organisme sehingga proses perombakan bahan organik terjadi lebih cepat dalam tanah. Pupuk 
kandang sapi juga dapat meningkatkan kemampuan tanah untuk menyimpan air yang nantinya berfungsi untuk mineralisasi bahan organik menjadi hara yang dapat dimanfaatkan langsung oleh tanaman selama masa pertumbuhannya.

Selain pemberian bahan organik berupa pupuk kandang, perbaikan sifat fisik pada tanah Ultisol dapat juga dilakukan dengan penggunaan bahan-bahan yang tergolong sebagai pembenah tanah diantaranya pemanfaatan limbah pertanian berupa biochar. Bahan organik ini sulit lapuk, dan setelah diproses dengan teknik phyrolisis dapat dimanfaatkan sebagai pembenah tanah, yang diantaranya berperan dalam meningkatkan kemampuan tanah menahan air.

Aplikasi biochar dan pupuk kandang mampu meningkatkan kesuburan tanah sehingga dapat meningkatkan pertumbuhan dan hasil tanaman. Biochar berfungsi menahan air, melindungi tanah dari erosi dan mengikat unsur hara N, Ca. K dan Mg (Mateus, $d k k$., 2017), pupuk kandang banyak menyediakan unsur hara tersebut sehingga dengan kombinasi keduanya akan membantu unsur-unsur hara tersebut tetap berada di dalam tanah dan mampu meretensi air dalam tanah sehingga membantu mencegah terjadinya kehilangan hara akibat pencucian /leaching dan nantinya berfungsi untuk mineralisasi bahan organik menjadi hara yang dapat dimanfaatkan langsung oleh tanaman selama masa pertumbuhannya.

Penelitian ini dilakukan untuk mengetahui respon tanaman jagung kultivar Bisma terhadap kombinasi pemberian biochar sabut kelapa dengan pupuk kandang sapi

\section{Tempat dan Waktu Penelitian}

\section{METODE PENELITIAN}

Penelitian dilaksanakan di Teaching and Research Farm Fakultas Pertanian Universitas Jambi Desa Mendalo Darat, Kecamatan Jambi Luar kota, Kabupaten Muaro Jambi dengan ketinggian tempat $\pm 35 \mathrm{~m}$ dpl. Penelitian dilaksanakan selama 4 bulan, dari bulan Mei hingga Agustus 2019.

\section{Bahan dan Alat}

Bahan yang digunakan dalam penelitian ini adalah benih tanaman jagung kultivar Bisma, biochar sabut kelapa, pupuk kandang sapi dan Furadan. Alat yang digunakan adalah cangkul, gembor, ember,parang, tugal, tali rafia, label, meteran, timbangan, kamera dan alat tulis.

\section{Rancangan Percobaan}

Penelitian ini menggunakan Rancangan Acak Kelompok (RAK) 2 faktor. Faktor pertama biochar sabut kelapa (b) dengan 3 taraf, tanpa pemberian biochar sabut kelapa (b0), 5 ton ha ${ }^{-1}$ (b1), dan 10 ton ha ${ }^{-1}$ (b2). Faktor kedua adalah pupuk kandang sapi (p) dengan 3 taraf ; tanpa pemberian pupuk kandang sapi (p0), 15 ton ha ${ }^{-1}$ (p1), dan 30 ton ha ${ }^{-1}$ (p2) sehingga diperoleh 9 kombinasi perlakuan, yakni b0p0, b0p1, b0p2, b1p0, b1p1, b1p2, b2p0, b2p1, dan b2p2. Setiap satuan percobaan diulang sebanyak 3 kali sehingga diperoleh 27 satuan percobaan. Lahan yang digunakan dibersihkan dari kotoran, dan gulma. Kemudian tanah diolah dengan menggunakan cangkul. Selanjutnya dibuat petakan petakan percobaan dengan ukuran $3,0 \mathrm{~m}$ x 1,5 m sebanyak 27 petak. Jarak petak dalam ulangan 0,5 $\mathrm{m}$ dan jarak petak antar ulangan $1,0 \mathrm{~m}$.

\section{Pelaksanaan Penelitian \\ Persiapan Areal Percobaan}

Persiapan areal penelitian meliputi pembersihan areal penelitian dari kotoran dan gulma. Tanah diolah menggunakan cangkul. Luas lahan yang digunakan adalah $19,5 \mathrm{~m} \mathrm{x} 13 \mathrm{~m}$. Setelah pengolahan tanah, dilakukan pembuatan petakan percobaan dengan ukuran $3 \mathrm{~m}$ x 1,5 m sebanyak 27 petak. Jarak petak dalam ulangan 0,5 $\mathrm{m}$ dan jarak petak antar ulangan $1 \mathrm{~m}$.

\section{Aplikasi Perlakuan}

Biochar sabut kelapa yang digunakan berasal dari sabut kelapa yang dibakar secara tidak sempurna hingga menjadi biochar. Aplikasi biochar sabut kelapa dilakukan seminggu setelah pemberian pupuk kandang. Biochar disebar di atas permukaan tanah dengan dosis sesuai perlakuan, kemudian diaduk merata ke dalam tanah menggunakan cangkul

Pupuk kandang sapi yang digunakan pada penelitian ini adalah pupuk kandang yang sudah jadi (matang). Aplikasi pupuk kandang sapi dilakukan 2 minggu sebelum penanaman. Pupuk kandang diberikan dengan cara menyebarkan pada petakan dengan dosis sesuai perlakuan. Kemudian diaduk merata ke dalam tanah menggunakan cangkul.

\section{Penanaman}

Penanaman dilakukan satu minggu setelah pemberian biochar dengan cara tugal. Pada setiap lubang tanam diberi Furadan dengan tujuan mencegah serangan serangga terhadap benih. Dalam satu petakan terdapat 24 lubang 
Ledi Aprillia Pelawi, Mapegau, dan Yulia Alia. Respon Tanaman Jagung (Zea mays L.) Terhadap Pemberian Biochar Sabut Kelapa dan Pupuk Kandang Sapi

tanam, dalam satu lubang tanam ditanam 2 butir benih jagung sehingga dalam satu petakan dibutuhkan 48 butir benih jagung. Jarak tanam yang digunakan adalah $75 \mathrm{~cm} \times 25 \mathrm{~cm}$.

\section{Variabel Pengamatan}

1. Pertumbuhan tanaman meliputi: Tinggi tanaman, dikukur pada saat tanaman berumur 6 MST. Luas daun total, dikukur pada saat tanaman berumur 8 MST.

2. Komponen hasil dan hasil meliputi : Bobot biji pertongkol, dihitung dalam satuan gram (g) dan hasil (ton ha $\left.{ }^{1}\right)$ dihitung dengan menggunakan rumus:

$$
\text { Hasil ton } \mathrm{ha}^{-1}=\frac{10.000 \mathrm{~m}^{2}}{\text { luas petak produksi } \mathrm{m}^{2}} \times \text { Hasil petak ubinan gram) } \times 10^{-6}
$$

\section{Analisis Data}

Data hasil penelitian dianalisis menggunakan sidik ragam, jika berbeda nyata maka dilanjutkan dengan Uji Beda Nyata Terkecil (BNT) pada taraf $\mathrm{p}=0,05$.

\section{Tinggi Tanaman}

\section{HASIL DAN PEMBAHASAN}

Hasil penelitian menunjukkan bahwa interaksi antara perlakuan biochar sabut kelapa dengan pupuk kandang sapi dan faktor pemberian biochar sabut kelapa tidak berpengaruh nyata terhadap tinggi tanaman, tetapi faktor pemberian pupuk kandang sapi berpengaruh nyata terhadap tinggi tanaman (Tabel 1).

Tabel 1. Rata-Rata Tinggi Tanaman pada Pemberian Biochar Sabut Kelapa dan Pupuk Kandang Sapi.

\begin{tabular}{ccccc}
\hline \multirow{2}{*}{ Biochar Sabut Kelapa (ton ha $\left.{ }^{-1}\right)$} & \multicolumn{3}{c}{ Pupuk Kandang Sapi (ton ${ }^{-1}$ ) } & \multirow{2}{*}{ Rata-rata } \\
\cline { 2 - 4 } & $\mathrm{p} 0(0)$ & $\mathrm{p} 1(15)$ & $\mathrm{p} 2(30)$ & \\
\hline & & ----- Tinggi tanaman $(\mathrm{cm})$------ & \\
b0 (0) & 175,27 & 191,06 & 200,93 & $189,09 \mathrm{a}$ \\
b1 (5) & 185,43 & 212,21 & 210,89 & $202,84 \mathrm{a}$ \\
b2 (10) & 200,43 & 208,85 & 211,53 & $206,94 \mathrm{a}$ \\
Rata-rata & $187,04 \mathrm{a}$ & $204,04 \mathrm{~b}$ & $207,79 \mathrm{~b}$ & \\
\hline
\end{tabular}

Keterangan: Angka-angka yang diikuti oleh huruf yang sama berbeda tidak nyata menurut Uji BNT pada taraf $\mathrm{p}=$ $5 \%$.

Pemberian pupuk kandang sapi dengan dosis 15 ton ha ${ }^{-1}$ dan 30 ton ha ${ }^{-1}$ secara nyata meningkatkan tinggi tanaman jagung dibandingkan dengan tanpa pemberian pupuk kandang sapi, tetapi tinggi tanaman pada kedua dosis tersebut tidak berbeda nyata. Hal ini disebabkan pemberian pupuk kandang sapi memberi tambahan unsur hara N, P dan K di dalam tanah. Peningkatan kadar nitrogen tanah akan meningkat pula kadar nitrogen pada jaringan tanaman. Semakin tinggi kadar nitrogen pada jaringan mengakibatkan pertumbuhan tanaman semakin terpacu (Sufardi, 2019). Unsur Nitrogen $(\mathrm{N})$ berperan dalam merangsang pertumbuhan vegetatif yaitu dalam penambahan tinggi tanaman dan jumlah daun. Menurut Ginting (2019) nitrogen merupakan unsur yang diperlukan untuk pertumbuhan vegetatif tanaman terutama daun, pertambahan tunas dan tinggi tanaman.

\section{Luas Daun Total}

Hasil penelitian menunjukkan bahwa interaksi antara perlakuan biochar sabut kelapa dengan pupuk kandang sapi dan faktor biochar sabut kelapa secara mandiri tidak berpengaruh nyata terhadap luas daun total. Hanya pupuk kandang sapi secara mandiri berpengaruh nyata terhadap luas daun total (Tabel 2).

Tabel 2. Rata-Rata Luas Daun Total pada Pemberian Biochar Sabut Kelapa dan Pupuk Kandang Sapi.

\begin{tabular}{|c|c|c|c|c|}
\hline \multirow{2}{*}{$\begin{array}{c}\text { Biochar Sabut Kelapa } \\
\left(\text { ton } \mathrm{ha}^{-1}\right)\end{array}$} & \multicolumn{3}{|c|}{ Pupuk Kandang Sapi (ton $\left.{ }^{-1}\right)$} & \multirow{2}{*}{ Rata-rata } \\
\hline & p0 (0) & $\mathrm{p} 1(15)$ & $\mathrm{p} 2(30)$ & \\
\hline & \multicolumn{4}{|c|}{------Luas daun total $\left(\mathrm{cm}^{2}\right)$------- } \\
\hline bo $(0)$ & 6262,13 & 6962,48 & 7139,42 & $6788,01 \mathrm{a}$ \\
\hline b1 (5) & 6786,05 & 7383,21 & 7330,70 & $7166,65 \mathrm{a}$ \\
\hline b2 (10) & 7108,60 & 7282,91 & 7385,03 & $7258,84 \mathrm{a}$ \\
\hline Rata-rata & $6718,93 \mathrm{a}$ & $7209,53 \mathrm{~b}$ & $7285,05 \mathrm{~b}$ & \\
\hline
\end{tabular}

Keterangan: Angka-angka yang diikuti oleh huruf yang sama berbeda tidak nyata menurut Uji BNT pada taraf $\mathrm{p}=5 \%$. 
Pemberian pupuk kandang sapi dengan dosis 15 ton ha ${ }^{-1}$ dan 30 ton $^{-1}$ secara nyata meningkatkan luas daun total dibandingkan dengan tanpa pemberian pupuk kandang sapi, tetapi luas daun total pada kedua dosis tersebut tidak berbeda nyata. Hal ini disebabkan pupuk kandang sapi mampu meningkatkan pertumbuhan daun tanaman karena pupuk kandang sapi memberi tambahan unsur N, P dan K. di dalam tanah. Meningkatnya kadar nitrogen tanah meningkatkan pula kadar nitrogen pada jaringan tanaman. Semakin tinggi kadar nitrogen pada jaringan mengakibatkan pertumbuhan tanaman semakin terpacu, sehingga dapat menyebabkan tanaman menjadi lebih tinggi, diameter batang lebih lebar, jumlah daun lebih banyak, daun akan tumbuh besar dan memperluas permukaannya (Sufardi, 2019).

\section{Bobot biji per tongkol}

Hasil penelitian menunjukkan bahwa interaksi antara perlakuan biochar sabut kelapa dengan pupuk kandang sapi biochar dan faktor sabut kelapa secara mandiri tidak berpengaruh nyata terhadap bobot biji per tongkol, tetapi, pemberian pupuk kandang sapi berpengaruh nyata terhadap berat biji per tongkol (Tabel 3).

Tabel 3. Rata-Rata Berat Biji Per Tongkol pada Pemberian Biochar Sabut Kelapa dan Pupuk Kandang Sapi.

\begin{tabular}{ccccc}
\hline \multirow{2}{*}{ Biochar Sabut Kelapa $\left(\right.$ ton ha $\left.^{-1}\right)$} & \multicolumn{3}{c}{ Pupuk Kandang Sapi (ton $\left.{ }^{-1}\right)$} & \multirow{2}{*}{ Rata-rata } \\
\cline { 2 - 4 } & $\mathrm{p} 0(0)$ & $\mathrm{p} 1(15)$ & $\mathrm{p} 2(30)$ & \\
\hline & & ---- Berat biji per tongkol $($ gram $)-----$ & \\
b0 (0) & 121,67 & 130,5 & 136,83 & $129,67 \mathrm{a}$ \\
b1 (5) & 127,75 & 137,08 & 134,67 & $133,17 \mathrm{a}$ \\
b2 (10) & 131,58 & 133,5 & 136,58 & $133,89 \mathrm{a}$ \\
Rata-rata & $127,00 \mathrm{a}$ & $133,69 \mathrm{~b}$ & $136,03 \mathrm{~b}$ & \\
\hline
\end{tabular}

Keterangan: Angka-angka yang diikuti oleh huruf yang sama berbeda tidak nyata menurut $U j i$ BNT pada taraf $\mathrm{p}=5 \%$.

Pemberian pupuk kandang sapi dengan dosis 15 ton ha ${ }^{-1}$ dan 30 ton ha ${ }^{-1}$ secara nyata meningkatkan bobot biji per tongkol dibandingkan dengan tanpa pemberian pupuk kandang sapi, tetapi bobot biji per tongkol pada kedua dosis tersebut tidak berbeda nyata. Tanaman jagung memberikan hasil yang maksimum karena tersedianya unsur hara yang cukup dan tersedia bagi tanaman, karena pada fase generatif juga membutuhkan unsur hara tidak berbeda dengan fase vegetatif. Tanaman jagung membutuhkan nitrogen sepanjang hidupnya dan sangat efektif dalam penggunaan amonium meskipun sebagian besar diambil dalam bentuk nitrat (Sudjana et al., 1991). Novriani (2010) menambahkan bahwa $\mathrm{P}$ pada masa generatif dialokasikan pada proses pembentukan biji atau buah tanaman. Lebih lanjut Mapegau (2010) menyatakan bahwa P berfungsi sebagai sumber energi dalam berbagai reaksi metabolisme tanaman berperan penting dalam peningkatan hasil serta memberikan banyak fotosintat yang didistribusikan ke dalam biji sehingga hasil biji tanaman jagung meningkat.

Tidak adanya perbedaan nyata tinggi tanaman, luas daun total, dan bobot biji per tongkol antara perlakuan p1 dengan p2 diduga disebabkan pemberian pupuk kandang 15 ton ha ${ }^{-1}$ sudah dapat memenuhi kebutuhan unsur hara NPK untuk tanaman yang diujikan.

\section{Hasil Tanaman Jagung}

Hasil penelitian menunjukkan bahwa pemberian biochar sabut kelapa serta interaksi antara perlakuan biochar sabut kelapa dengan pupuk kandang sapi tidak berpengaruh nyata terhadap hasil tanaman jagung. Secara mandiri pemberian pupuk kandang sapi berpengaruh nyata terhadap hasil tanaman jagung (Tabel 4).

Tabel 4. Rata-Rata Hasil Tanaman Jagung pada Pemberian Biochar Sabut Kelapa dan Pupuk Kandang Sapi.

\begin{tabular}{ccccc}
\hline \multirow{2}{*}{ Biochar Sabut Kelapa $\left(\right.$ ton $\left.\mathrm{ha}^{-1}\right)$} & \multicolumn{3}{c}{ Pupuk Kandang Sapi (ton ha $\left.{ }^{-1}\right)$} & \multirow{2}{*}{ Rata-rata } \\
\cline { 2 - 3 } & $\mathrm{p} 0(0)$ & $\mathrm{p} 1(15)$ & $\mathrm{p} 2(30)$ & \\
\hline & & ----- Hasil tanaman jagung $\left(\right.$ ton ha $\left.^{-1}\right)$------- & \\
b0 (0) & 5,49 & 5,83 & $6,87 \mathrm{a}$ \\
b1 (5) & 5,81 & 6,31 & 6,18 & $6,10 \mathrm{a}$ \\
b2 (10) & 6,02 & 6,12 & 6,28 & $6,14 \mathrm{a}$ \\
Rata-rata & $5,77 \mathrm{a}$ & $6,09 \mathrm{ab}$ & $6,25 \mathrm{~b}$ & \\
\hline
\end{tabular}

Keterangan: Angka-angka yang diikuti oleh huruf yang sama berbeda tidak nyata menurut Uji BNT pada taraf $\mathrm{p}=5 \%$.

Pemberian pupuk kandang sapi secara nyata dapat meningkatkan hasil tanaman jagung. Pada pemberian dosis 15 ton ha $^{-1}$ peningkatan hasil tanaman belum menunjukkan perbedaan yang nyata dengan tanpa pemberian pupuk kandang sapi. Penambahan dosis pupuk kandang sapi menjadi 30 ton ha ${ }^{-1}$ mampu meningkatkan hasil 
tanaman nyata dibandingkan dengan tanpa pemberian pupuk kandang sapi. Pada fase reproduktif tidak seluruh karbohidrat dipergunakan untuk perkembangan batang, daun, dan perakaran; sebagian disisakan untuk perkembangan bunga, buah, dan biji. Advinda (2018) menambahkan, bahwa jika kebutuhan unsur hara tanaman terpenuhi, maka tanaman akan lebih optimal dalam proses metabolisme hidup dalam jaringan yaitu dalam meningkatkan proses fotosintesis dan menghasilkan fotosintat yang sangat membantu pembelahan sel dan pembesaran sel sehingga tanaman dapat tumbuh dan menghasilkan produksi yang maksimal yang ditunjukkan dengan perkembangan organ-organ yang baik dan unsur hara $\mathrm{N}$ bersama dengan $\mathrm{P}$ akan membentuk protein, karbohidrat, asam nukleat yang diatur dan ditranslokasikan ke seluruh jaringan tanaman oleh K. Sejalan dengan hal tersebut menurut Mapegau (2010) dengan meningkatnya serapan N, P, dan K dan jumlah klorofil dapat meningkatkan laju fotosintesis yang kemudian akan meningkatkan hasil tanaman.

Dari semua parameter yang diamati, terlihat bahwa interaksi pemberian perlakuan biochar sabut kelapa dengan pupuk kandang sapi maupun faktor biochar secara mandiri tidak berpengaruh nyata terhadap pertumbuhan dan produksi tanaman jagung, kondisi ini diduga karena tanaman jagung belum merespon fungsi dari biochar ini selama rentang waktu penelitian sehingga belum ada perbedaan nyata pertumbuhan dan produksi tanaman.

\section{KESIMPULAN}

Tidak ada interaksi nyata pemberian biochar sabut kelapa dan pupuk kandang sapi terhadap pertumbuhan dan hasil tanaman jagung. Pemberian biochar sabut kelapa belum mempengaruhi tinggi tanaman, jumlah daun, luas daun total, bobot biji per tongkol, dan hasil tanaman jagung. Pemberian pupuk kandang sapi dengan dosis 15 ton ha dapat meningkatkan tinggi tanaman, luas daun total, berat biji per tongkol dan hasil tanaman jagung.

\section{DAFTAR PUSTAKA}

Advinda, L. 2018. Dasar-Dasar Fisiologi Tumbuhan. Deepublish. Jogjakarta.

Badan Litbang Pertanian. 2012. Statistik Badan Penelitian dan Pengembangan Pertanian. Jakarta (ID): Balitbangtan.

Kementan. 2013. Data Statistik Ketahanan Pangan tahun 2012.Jakarta (ID):Badan Ketahanan Pangan Kementerian Pertanian 2013.

Kementan. 2016. Empat Permasalahan Jagung Nasional dari Sisi Produksi. https://www.medcom.id/ekonomi/mikro/9K5GYjnb-empat-permasalahan-jagung-nasional-dari-sisi-produksi

Ginting, C. 2019. Nutrisi Tanaman. Instiper Press. Jogjakarta.

Mapegau. 2010. Pengaruh Pemupukan N dan P Terhadap Pertumbuhan dan Hasil Tanaman Jagung. Fakultas Pertanian Universitas Jambi. Jurnal Penelitian Universitas Jambi Seri Sains. 12(2):33-36.

Mateus, R., D. Kantur, dan L.M. Moy. 2017. Pemanfaatan Biochar Limbah Pertanian Sebagai Pembenah Tanah Untuk Perbaikan Kualitas Tanah dan Hasil Jagung Di Lahan Kering. Agrotrop 7 (2) 99-108.

Novriani. 2010. Alternatif Pengelolaan Unsur Hara P (Fosfor) pada Budidaya Jagung. Jur. AgronobiS. Vol. 2 (3). $42-$ 49.

Sudjana, A., A. Rifin, dan M. Sudjadi. 1991. Jagung. Balitbangtan Balai Penelitian Tanaman Pangan. Bogor. Buletin Teknik No. 3.

Sufardi, 2019. Pengantar Nutrisi Tanaman. Cetakan kedua. Syiah Kuala University Press. Banda Aceh 